RASĀYAN J. Chem.

Vol. 13 | No. 3 |1801-1806| July - September | 2020 ISSN: 0974-1496 | e-ISSN: 0976-0083 | CODEN: RJCABP

\title{
THE EFFECT OF VARIOUS PHENOLICS IN $p$-TsOH- CATALYZED SOLVENT-FREE MICROWAVE-ASSISTED SYNTHESIS OF 4-METHYL COUMARIN DERIVATIVES
}

\author{
H. Dianhar ${ }^{1}$, A. W. Winata ${ }^{2}$, S. Handayani ${ }^{2}$, P. Sugita ${ }^{3}$ and D. U. C. Rahayu ${ }^{2, *}$ \\ ${ }^{1}$ Chemistry Study Program, Faculty of Mathematics and Natural Sciences (FMIPA), Universitas \\ Negeri Jakarta, Jakarta 13220, Indonesia \\ ${ }^{2}$ Department of Chemistry, Faculty of Mathematics and Natural Sciences (FMIPA), Universitas \\ Indonesia, Depok 16424, Indonesia \\ ${ }^{3}$ Department of Chemistry, Faculty of Mathematics and Natural Sciences (FMIPA), IPB \\ University, Bogor 16680, Indonesia \\ *E-mail: dyahutamicr@sci.ui.ac.id
}

\begin{abstract}
Coumarin derivatives from natural and synthetic sources are an important class of heterocyclic compounds that displayed a broad spectrum of pharmacological properties. Among all coumarin derivatives, 4-methyl coumarin has been essentially used as a building block to afford various chemical structures. In this study, the effect of various phenolics and catalytic activity of $p-\mathrm{TsOH}$ for synthesizing 4-methyl coumarin derivatives has been investigated under conventional heating and microwave conditions. The highest yield of 4-methyl coumarin derivatives synthesis was achieved using resorcinol $(60.10 \pm 2.9 \%$ yield $)$ in the optimum reaction condition of starting materials molar ratio $(1: 1$, resorcinol/ethyl acetoacetate, $\mathrm{mol} / \mathrm{mol})$ and $10 \mathrm{~mol} \%$ of $p-\mathrm{TsOH}$ using $800 \mathrm{~W}$ microwave irradiation at $80^{\circ} \mathrm{C}$ for 180s under solvent-free condition. Microwave-assisted condition revealed a useful and simple method to synthesize coumarin derivatives through Pechmann condensation under neat and mild conditions with moderate to high yield, short reaction time, and easier product work-up using organic Brønsted acid catalyst.

Keywords: Pechmann Condensation, 4-Methyl Coumarin, Microwave-assisted, Solvent-free, Phenolics, and $p$-TsOH Catalyst.
\end{abstract}

(C) RASĀYAN. All rights reserved

\section{INTRODUCTION}

Coumarin, chemically known as $2 H$-1-benzopyran-2-one, and its derivatives are widely distributed as living organism's chemical constituents. ${ }^{1}$ This compound is an important and a well-known class of heterocyclic natural products which broadly utilized in pharmaceuticals, fragrances, cosmetics, food additives, agrochemicals, and insecticides. ${ }^{2}$ Coumarin derivatives possess in a pharmaceutical application since they demonstrated broad biological activities on current health issues such as antioxidant, anticancer, antimicrobial, antibacterial, antifungal, antiviral, anti-allergic, anti-inflammatory, blood anticoagulants, antihypertensive, anti-HIV, anti-hepatitis, antimalarial, anti-Alzheimer's, antidiabetic, anticonvulsant, antithrombotic, tyrosinase inhibitor, neuroprotective, and hepatoprotective. ${ }^{3-6}$ Also, they are commonly employed as optical functional materials for Organic Light-Emitting Diodes (OLEDs), dye-sensitized solar cells, and fluorescent dyes and probes. ${ }^{7}$

The synthesis of coumarin derivatives has captured organic chemists' attention towards the development of novel and well-organized methodologies recently. Coumarin derivatives have become the most popular to attract longstanding synthetic interest due to its efficient, diverse, and relatively easy to synthesis. ${ }^{7-9}$ Coumarin scaffold, possessing a system of fused benzene and $\alpha$-pyrone rings, has been well reported to be synthesized via various methods acquainted by Knoevenagel, Claisen, Pechmann, Perkin, Baylis-Hillman, Reformatsky, Wittig, and so forth. ${ }^{1,2,10}$ Amongst all, the Pechmann reaction has been extensively used in the preparation of 4 -substituted coumarins, one of the coumarin derivatives which has been essentially

Rasayan J. Chem., 13(3), 1801-1806(2020)

http://dx.doi.org/10.31788/ RJC.2020.1335808

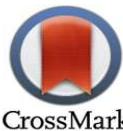


exploited as an ideal framework and a privileged scaffold to afford chemically and biologically diverse agents. ${ }^{10-12}$ Specifically, this reaction occurs through the formation of phenolics and $\beta$-ketoesters coupling in slightly acidic conditions. ${ }^{10}$

Recent reports have presented a new paradigm in the preparation of organic molecules that possess technology development to achieve high efficiency and support green chemistry. In this instance, microwave irradiation has emerged as a revolutionized method for accelerating organic synthesis. ${ }^{8}$ The use of microwave in organic synthesis in the last years has been increasing rapidly since it provides convenient and clean synthesis route with enhancing reaction rates, offer higher yields and greater selectivity, achieve greater reproducibility, environmental-friendly, and affordable low-cost with the possibility to conduct under solvent-free conditions. ${ }^{13-15}$ Following our interest on the solvent-free microwave-assisted heterocyclic compounds synthesis, herein we explain our findings of the effect of various phenolics and catalytic activity of $p$-TsOH as Brønsted acid catalyst for preparing 4-methyl coumarin derivatives followed Pechmann condensation in a neat condition under microwave irradiation. ${ }^{16-19}$

\section{General Procedures}

\section{EXPERIMENTAL}

The microwave-assisted synthesis was performed by using $800 \mathrm{~W}$ domestic microwave Samsung ME$731 \mathrm{~K} / \mathrm{XSE}$. The structure of 4-methyl coumarin derivatives was elucidated using Fourier Transform InfraRed (FTIR) Shimadzu IR Prestige 21, Ultraviolet-Visible (UV-Vis) Shimadzu UV-2450, and Nuclear Magnetic Resonance (NMR) Agilent 500 instrument operating at $500 \mathrm{MHz}\left({ }^{1} \mathrm{H}\right)$ and $125 \mathrm{MHz}\left({ }^{13} \mathrm{C}\right)$. The melting point was measured using Electrothermal Melting Temp. Apparatus. Thin-layer chromatography (TLC) was conducted using Merck pre-coated silica gel plates ( $\mathrm{Si} 60 \mathrm{GF}_{254}, 0.25 \mathrm{~mm}$ thickness). TLC analyses were performed under $254 \mathrm{~nm}$ UV light. The chemicals used for synthesis were phenol, resorcinol, phloroglucinol, ethyl acetoacetate, $p$-toluene sulfonic acid ( $p$-TsOH), xylene, ethanol, $n$-hexane, and ethyl acetate. All chemicals were purchased from Merck without any purification before use.

\section{Microwave-Assisted Synthesis of 4-Methyl Coumarin Derivatives}

The reaction of resorcinol with ethyl acetoacetate was selected as a reference for reaction parameters optimization. Resorcinol ( $1 \mathrm{mmol}, 0.1101 \mathrm{~g})$ was mixed in crucible with various mole of ethyl acetoacetate (1 $(0.1275 \mathrm{ml}), 1.5(0.255 \mathrm{ml})$, and $2 \mathrm{mmol}(0.3825 \mathrm{ml}))$ to yield the starting materials molar ratio of $1: 1$, $1: 2$, and $1: 3$ (resorcinol/ethyl acetoacetate, $\mathrm{mol} / \mathrm{mol}$ ), respectively. $p$-TsOH as catalyst was also added to the mixture in various concentrations depended on resorcinol mol $(0,5,10$, and $15 \%)$. The crucible then was neatly irradiated by using an $800 \mathrm{~W}$ microwave for various reaction times $(150,180,210$, and $240 \mathrm{~s})$. The mixture was gradually monitored by using an infrared thermometer and TLC. After completing the reaction, the mixture then was cooled, washed with ethanol-water, and recrystallized using warm ethanol. Moreover, the compound then was measured for its melting point and further elucidated by using FTIR, UV-Vis, and NMR. Similar reactions were also conducted using various phenolics, i.e. phenol $(1 \mathrm{mmol}$, $0.1261 \mathrm{~g}$ ) and phloroglucinol ( $1 \mathrm{mmol}, 0.0941 \mathrm{~g})$, by using the optimum condition obtained for resorcinol. All the synthesized procedures were carried out in duplicate.

\section{Synthesis of 7-Hydroxy-4-Methyl Coumarin using Conventional Heating}

7-Hydroxy-4-methyl coumarin was synthesized according to the optimum condition described previously with some modification. ${ }^{20}$ Resorcinol $(1 \mathrm{mmol}, 0.1101 \mathrm{~g})$, ethyl acetoacetate $(1 \mathrm{mmol}, 0.1275 \mathrm{ml})$, and $p$ $\mathrm{TsOH}(10 \%$ mole of resorcinol) were dissolved in several amounts of xylene in a three-neck round-bottom flask. The mixture then was refluxed at $110^{\circ} \mathrm{C}$ for 2 hours. Several works up reactions were also carried out. The compound then was finally characterized by using FTIR.

\section{Physical Properties and Spectral Data of 4-Methyl Coumarin Derivatives}

7-Hydroxy-4-methyl coumarin: $\mathrm{C}_{10} \mathrm{H}_{8} \mathrm{O}_{3}$, pale yellow solid, $\mathrm{R}_{\mathrm{f}} 0.45$ in $n$-hexane:ethyl acetate $(6: 4, \mathrm{v} / \mathrm{v})$, m.p. $\left({ }^{\circ} \mathrm{C}\right): 189-190, v_{\max }$ FTIR in $\mathrm{KBr}\left(\mathrm{cm}^{-1}\right): 3,483.4(\mathrm{O}-\mathrm{H}), 3,100.2\left(\mathrm{C}-\mathrm{H} s p^{2}\right), 2,866.3-2,933.3\left(\mathrm{C}-\mathrm{H} s p^{3}\right)$, $1,667.7(\mathrm{C}=\mathrm{O}), 1,601.6(\mathrm{C}=\mathrm{C}), 1,068.5(\mathrm{C}-\mathrm{O}), \lambda_{\max } \mathrm{UV}-\mathrm{Vis}$ in $\mathrm{MeOH}(\mathrm{nm}): 325,{ }^{1}{ }^{1} \mathrm{H}-\mathrm{NMR}(\mathrm{ppm})$ in 500 
RASĀYAN J. Chem.

Vol. 13 | No. 3 |1801-1806| July - September | 2020

MHz acetone- $d_{6}: 9.39(1 \mathrm{H}, s, 7-\mathrm{OH}), 7.60(1 \mathrm{H}, \mathrm{d}, J=8.7 \mathrm{~Hz}, \mathrm{H}-5), 6.86(1 \mathrm{H}, \mathrm{dd}, J=8.7,2.4 \mathrm{~Hz}, \mathrm{H}-8)$, $6.73(1 \mathrm{H}, \mathrm{d}, J=2.4 \mathrm{~Hz}, \mathrm{H}-6), 6.07(1 \mathrm{H}, \mathrm{s}, \mathrm{H}-3), 2.41(3 \mathrm{H}, \mathrm{s}, \mathrm{H}-11), \delta{ }^{13} \mathrm{C}-\mathrm{NMR}(\mathrm{ppm})$ in $125 \mathrm{MHz}$ acetone$d_{6}$ : 161.9 (C-2), 161.0 (C-7), 156.4 (C-9), 153.8 (C-4), 127.3 (C-5), 113.7 (C-6), 113.5 (C-10), 111.8 (C3), 103.3 (C-8), 18.5 (C-11).

5,7-Dihydroxy-4-methyl coumarin: $\mathrm{C}_{10} \mathrm{H}_{8} \mathrm{O}_{4}$, yellow solid, $\mathrm{R}_{\mathrm{f}} 0.12$ in $n$-hexane:ethyl acetate (8:2, v/v), m.p. $\left({ }^{\circ} \mathrm{C}\right): 295-297, v_{\max }$ FTIR in $\mathrm{KBr}\left(\mathrm{cm}^{-1}\right): 3,196.4-3,482.1(\mathrm{O}-\mathrm{H}), 2,928.6\left(\mathrm{C}-\mathrm{H} s p^{3}\right), 1,625.8(\mathrm{C}=\mathrm{O}), 1,503.4$ $(\mathrm{C}=\mathrm{C}), 1,160.7(\mathrm{C}-\mathrm{O}), \lambda_{\max } \mathrm{UV}-\mathrm{Vis}$ in $\mathrm{MeOH}(\mathrm{nm}): 321, \delta{ }^{1} \mathrm{H}-\mathrm{NMR}(\mathrm{ppm})$ in $500 \mathrm{MHz}$ acetone- $d_{6}: 9.54$ $(1 \mathrm{H}, \mathrm{s}, 7-\mathrm{OH}), 9.28(1 \mathrm{H}, \mathrm{s}, 5-\mathrm{OH}), 6.35(1 \mathrm{H}, \mathrm{d}, J=2.4 \mathrm{~Hz}, \mathrm{H}-8), 6.27(1 \mathrm{H}, \mathrm{d}, J=2.4 \mathrm{~Hz}, \mathrm{H}-6), 5.83(1 \mathrm{H}$, s, H-3), 2.55 (3H, s, H-11), $\delta{ }^{13} \mathrm{C}-\mathrm{NMR}(\mathrm{ppm})$ in $125 \mathrm{MHz}$ acetone- $d_{6}: 161.8$ (C-2), $160.8(\mathrm{C}-7), 158.5$ (C5), 158.0 (C-9), 155.4 (C-4), 110.6 (C-3), 100.0 (C-10), 99.9 (C-6), 96.0 (C-8), 23.9 (C-11).

\section{RESULTS AND DISCUSSION}

In this study, the variety of 4-methylcoumarin has successfully synthesized following Pechmann condensation under microwave-assisted conditions. Pechmann condensation was selected since it proceeds a valuable method for coumarin synthesis from a very commonly used starting materials and affords good yields of desired products. ${ }^{20}$ The Pechmann reaction requires energy from heating by conventional or microwave irradiation..$^{10}$ The latest insight on the mechanism of the Pechmann condensation reveals that the synthesis route is featuring the sequence of three-step mechanism i.e. initial trans-esterification followed by intramolecular electrophilic aromatic substitution and final water elimination. ${ }^{21-22}$

Optimization of the reaction parameters under microwave condition was carried out for the described reaction (Fig.-1). Moreover, this model reaction has also been conducted under the conventional heating conditions to compare the results and effectiveness of the synthesis. Initially, an $800 \mathrm{~W}$ domestic microwave was set up to choose the best conditions using starting materials molar ratio of 1:1 (resorcinol/ethyl acetoacetate, $\mathrm{mol} / \mathrm{mol}$ ) and $10 \mathrm{~mol} \% p$-TsOH catalyst under solvent-free condition. $p$-TsOH was selected as a catalyst since this organic acid provides a mild catalysis condition, commercially available, inexpensive, and environmentally benign. ${ }^{23-25}$ Study on coumarins synthesis recently has been mainly focused on the inorganic acid catalyst, either Brønsted or Lewis acid., ${ }^{3,26-28}$ However, these catalysts reported to give by-products, less efficient in reaction time and cost, and lower in yields. ${ }^{20}$ Therefore, $p$ $\mathrm{TsOH}$ offers an alternative condition to offer more efficient, versatile, neat, and mild reaction for coumarins synthesis via the Pechmann condensation.

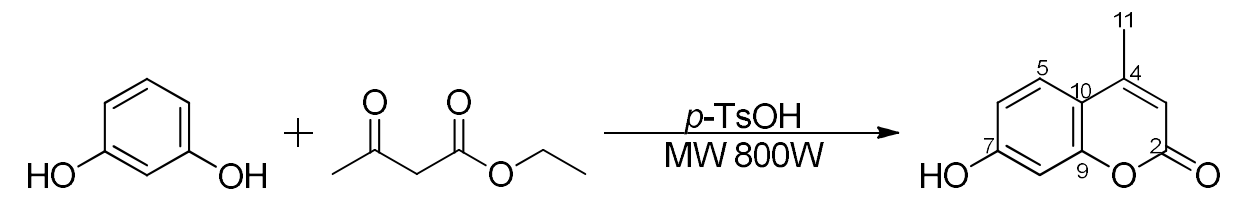

Fig.-1: Reaction Scheme of $p$-TsOH-catalyzed of 7-Hydroxy-4-Methyl Coumarin Synthesis Under Neat Condition Assisted by Microwave Irradiation

Table-1 summarized the comparison of conditions and optimization reaction parameter of microwaveassisted for the model synthesis. According to Table-1, by using microwave irradiation with the temperature was maintained at $80^{\circ} \mathrm{C}$ for $180 \mathrm{~s}$ afforded the highest yield of 7-hydroxy-4-methyl coumarin $(60.10 \pm 2.9)$ (Table-1, entry 2). The selection of this temperature due to by-products minimization. In our conditions, the higher temperature decreased the yield of the desired product and required further purification (data not shown). Furthermore, a decrease of the reaction time led to the lower yield (45.07 \pm 6.4$)$ (Table 1, entry 1), while an increase in reaction time decreased a pronounced yield even further $(41.20 \pm 1.6$ and $40.96 \pm 0.7)$ (Table-1, entry 3 and 4). The reduction yield at longer reaction time was found as results of by-products formation such as chromones, self-condensation of ethyl acetoacetate products, isomerization and cleavage of 7-hydroxy-4-methyl coumarin products. ${ }^{20}$ Subsequently, the variety of starting materials molar ratio (1:1.5 and $1: 2$, resorcinol/ethyl acetoacetate, $\mathrm{mol} / \mathrm{mol}$ ) affected in lower yields compared with $1: 1$ ( $\mathrm{mol} / \mathrm{mol}$ ) model reaction (Table-1, entry 2 ) with no significant differences between molar ratio of 1:1.5 $(\mathrm{mol} / \mathrm{mol})$ (Table-1, entry 5$)$ and 1:2 (mol/mol) (Table-1, entry 6) reactions. 
RASĀYAN J. Chem.

Vol. 13 | No. 3 |1801-1806| July - September | 2020

Table-1: Comparison of Conditions and Optimization Reaction Parameter of Microwave-assisted for the Synthesis of 4-Methyl Coumarin Derivative from Resorcinol

\begin{tabular}{|c|c|c|c|c|c|c|}
\hline Entry & Reaction Condition & Solvent & $\begin{array}{l}\text { Resorcinol/ethyl } \\
\text { acetoacetate Molar } \\
\text { Ratio (mol/mol) }\end{array}$ & $\begin{array}{l}p-\mathrm{TsOH} \\
\text { Catalyst } \\
(\% \mathrm{~mol})\end{array}$ & Time (s) & $\begin{array}{c}\text { Yields } \\
(\%)\end{array}$ \\
\hline 1 & $\mathrm{MW} 800 \mathrm{~W}, 80^{\circ} \mathrm{C}$ & - & $1: 1$ & 10 & 150 & $45.07 \pm 6.4$ \\
\hline 2 & $\mathrm{MW} 800 \mathrm{~W}, 80^{\circ} \mathrm{C}$ & - & $1: 1$ & 10 & 180 & $60.10 \pm 2.9$ \\
\hline 3 & $\mathrm{MW} 800 \mathrm{~W}, 80^{\circ} \mathrm{C}$ & - & $1: 1$ & 10 & 210 & $41.20+1.6$ \\
\hline 4 & $\mathrm{MW} 800 \mathrm{~W}, 80^{\circ} \mathrm{C}$ & - & $1: 1$ & 10 & 240 & $40.96 \pm 0.7$ \\
\hline 5 & $\mathrm{MW} 800 \mathrm{~W}, 80^{\circ} \mathrm{C}$ & - & $1: 1.5$ & 10 & 180 & $52.61 \pm 1.9$ \\
\hline 6 & $\mathrm{MW} 800 \mathrm{~W}, 80^{\circ} \mathrm{C}$ & - & $1: 2$ & 10 & 180 & $53.50 \pm 0.1$ \\
\hline 7 & $\mathrm{MW} 800 \mathrm{~W}, 80^{\circ} \mathrm{C}$ & - & $1: 1$ & 5 & 180 & $25.85+2.2$ \\
\hline 8 & $\mathrm{MW} 800 \mathrm{~W}, 80^{\circ} \mathrm{C}$ & - & $1: 1$ & 15 & 180 & $51.20 \pm 4.5$ \\
\hline 9 & $\mathrm{MW} 800 \mathrm{~W}, 80^{\circ} \mathrm{C}$ & - & $1: 1$ & 0 & 180 & n.d. \\
\hline 10 & Reflux, $110^{\circ} \mathrm{C}$ & Xylene & $1: 1$ & 10 & 7200 & 21.96 \\
\hline
\end{tabular}

The amount of catalyst was also optimized to observe the catalytic activity of $p$-TsOH in model reaction. By varying the amount of catalyst, the highest yield of 7-hydroxy-4-methyl coumarin was obtained with 10 $\mathrm{mol} \% p$-TsOH for microwave-mediated Pechmann condensation (Table-1, entry 2). The use of $5 \mathrm{~mol} \% p$ $\mathrm{TsOH}$ afforded a significant reduction in yield (Table-1, entry 7) and an increase of a catalyst amount to 15 mol\% could not improve the yield (Table-1, entry 7). Moreover, there was no observed yield from the uncatalyzed reaction (Table-1, entry 9). According to these results, it revealed that Pechmann condensation requires an acid catalyst, as mention previously. ${ }^{10}$ Acid catalyst plays a role in carbonyl activation by proton transfer to $\beta$-keto-ester to produce the trans-esterification intermediate product and release alcohol. Furthermore, activated carbonyl will be attacked by an aromatic ring at $\mathrm{C} 10$ (Figure 1) to afford the new ring and dehydration will be produced coumarin derivatives. ${ }^{22}$ In the reaction mechanism, the oxo form of activated carbonyl can undergo electrophilic aromatic substitution to the phenols in a more favorable way energetically in acidic condition thus it can be precluded the role of its enolic form. ${ }^{10}$

Aiming to obtain a direct comparison with the microwave irradiation method, the reaction between resorcinol and ethyl acetoacetate was also conducted with the addition of $10 \mathrm{~mol} \% p$-TsOH with conventional heating at $110^{\circ} \mathrm{C}$ in xylene as a solvent. The desired product, 7-hydroxy-4-methyl coumarin, was formed after $2 \mathrm{~h}(7200 \mathrm{~s})$ in $21.96 \%$ yield (Table-1, entry 10$)$. It was clear that the reaction was accelerated by assisting of microwave irradiation (Table-1, entry 2) since it reduced the reaction time. Besides, microwave-assisted synthesis also facilitates milder and solvent free-reactions with a higher yield.

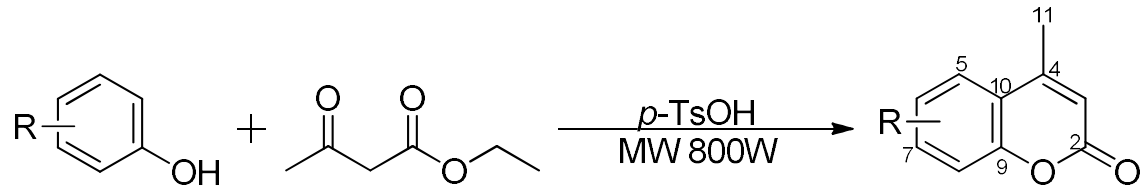

Fig.-2: Reaction Scheme of Microwave-assisted Synthesis of 4-Methyl Coumarin Derivatives Catalyzed by $p$-TsOH under Solvent-free Condition

To study the scope of the reaction using the obtained optimum conditions, various reactions using the series of phenols were also carried out (Fig.-2). As summarized in Table-2, a study on the reactivity of phenols was observed through a similar condition. The highest yield was obtained from resorcinol and ethyl acetoacetate (Table-2, entry 1). This result revealed that the presence of electron-donating groups (-OH at C7) activates the benzene to increase its nucleophilicity. Simultaneously, both hydroxyl groups in resorcinol will direct the next substitution in carbon at $\mathrm{C} 10$ (Fig.-2). The yield of the corresponding reaction with phloroglucinol (Table-2, entry 2) was found to be lower due to the steric hindrance. Moreover, under the same condition, the reaction between phenol and ethyl acetoacetate failed to afford the desired coumarin 
derivative (Table-2, entry 3). This result confirmed that the ring closure in coumarins formation mainly directed by the activating groups at ortho/para position(s), relative to O1. Activation of the benzene ring by the oxygen at $\mathrm{O} 1$ is much reduced after phenol-ester formation. However, some experiments have been succeeded to obtain the corresponding coumarin from phenol through different reaction conditions. ${ }^{26,29}$ Overall, by using microwave irradiation, conditions with obtained optimum reaction parameters afford the desired product of 7-hydroxy-4-methyl coumarin in either moderate to high yield or short reaction times. Further structure modification and biological activity investigation of 4-methyl coumarin derivatives are on-going in our laboratory.

Table-2: Synthesis of 4-Methyl Coumarin Derivatives through Pechmann Condensation of Phenol Derivatives with Ethyl Acetoacetate Catalyzed by $p$-TsOH

Entry

a Reaction Conditions: MW 800W, Solvent Free, Phenolic/ethyl acetoacetate Molar Ratio (1:1, mol/mol), 180 s Reaction Time, and $10 \mathrm{~mol} \%$ of $p$-TsOH

\section{CONCLUSION}

The effect of various phenolics and catalytic activity of $p-\mathrm{TsOH}$ for 4-methyl coumarin derivatives synthesis was successfully evaluated. Resorcinol was found to be the most reactive phenol derivatives among others. The role of $p$-TsOH as organic Brønsted acid catalyst in coumarin synthesis exhibited moderate to high catalytic activity. However, the microwave-assisted condition provides a useful and simple method to the Pechmann condensation affording moderate to high yield under the neat and mild condition in short reaction time with easier product work-up.

\section{ACKNOWLEDGEMENT}

The authors gratefully acknowledge the research funding from DRPM Universitas Indonesia through Hibah Publikasi Terindeks Internasional (PUTI) Prosiding 2020 No. NKB-963/UN2.RST/HKP.05.00/2020.

\section{REFERENCES}

1 B. S. Jayashree, S. Nigam, A. Pai and P. V. R. Chowdary, Arabian Journal of Chemistry, 7(6), 885(2014), DOI:10.1016/j.arabjc.2014.07.006.

2 N. H. Jadhav, S. S. Sakate, N. K. Rasal, D. R. Shinde and R. A. Pawar, ACS Omega, 4, 8522(2019), DOI: 10.1021/acsomega.9b00257.

3 A. Detsi, C. Kontogiorgis and D. Hadjipavlou-Litina, Expert Opinion on Therapeutic Patents, 27(11), 1201(2017), DOI:10.1080/13543776.2017.1360284.

4 K. Kasperkiewicz, M. B. Ponczek and E Budzisz, Pharmacological Reports, 70(6), 1057(2018), DOI:10.1016/j.pharep.2018.06.002.

5 Ambreen, S. Haque, V. Singh, D. Katiyar, M. T. A. Khan, V. Tripathi, H. E. Enshasy, M. Pasupuleti and B. N. Mishra, Process Biochemistry, 87, 138(2019), DOI:10.1016/j.procbio.2019.08.024. 
RASĀYAN J. Chem.

Vol. 13 | No. 3 |1801-1806| July - September | 2020

6 L. Zhang and Z. Xu, European Journal of Medicinal Chemistry, 181, 111587, 1(2019), DOI:10.1016/j.ejmech.2019.111587.

7 Y. Wang, Y. Li, T. Yu, W. Su, H. Ma, Y. Zhao, X. Li and H. Zhang, Dyes Pigments, 173, 107958, 1(2020), DOI:10.1016/j.dyepig.2019.107958.

8 N. Khaldi-Khellafi, D. Oukacha-Hikem, S. T. Bouaziz, A. Abdoun, M. Makhloufi-Chebli, F. Dumas, A. M. S. Silva and M. Hamdi, Chemical Data Collections, 25, 100341, 1(2020), DOI: $10.1016 / j . c d c .2020 .100341$.

9 J-C. Sun, J-L. Li, C-B. Ji, Y-Y. Peng and X-P. Zeng, Tetrahedron, 76(5), 130852, 1(2020), DOI: $10.1016 /$ j.tet.2019.130852.

10 K. C. Prousis, N. Avlonitis, G. A. Heropoulos and T. Calogeropoulou, Ultrasonics Sonochemistry, 21, 937(2014), DOI:10.1016/j.ultsonch.2013.10.018.

11 Y. Hu, W. Chen, Y. Shen, B. Zhu and G-X. Wang, Bioorganic \& Medicinal Chemistry Letters, 29(14), 1749(2019), DOI:10.1016/j.bmcl.2019.05.019.

12 K. Ostrowska, Saudi Pharmaceutical Journal, 28(2), 220(2020), DOI:10.1016/j.jsps.2019.11.025.

13 C. B. Patneedi, D. Prasadu, R. S. K. Sharma, D. C. Sekhar and D. V. V. Rao, Rasayan Journal of Chemistry, 8(2), 176(2015).

14 S. Dabrowska, T. Chudoba, J. Wojnarowicz and W. Lojkowski, Crystals, 8, 379, 1(2018), DOI: $10.3390 /$ cryst8100379.

15 S. Nain, R. Singh and S. Ravichandran, Advanced Journal of Chemistry, Section A, 2(2), 94(2019), DOI: 10.29088/SAMI/AJCA.2019.2.94104.

16 I. I. Lestari, D. U. C. Rahayu, D. A. Nurani, Y. K. Krisnandi and E. Budianto, AIP Conference Proceedings, 2168, 020066, 1(2019), DOI:10.1063/1.5132493.

17 A. Yuniastuti, D. U. C. Rahayu, D. A. Nurani, Y. K. Krisnandi and E. Budianto, AIP Conference Proceedings, 2168, 020067, 1(2019), DOI:10.1063/1.5132494.

18 S. Budiana, B. Andrana, D. U. C. Rahayu, D. A. Nurani, Y. K. Krisnandi and E. Budianto, IOP Conference Series: Materials Science and Engineering, 763, 012006, 1(2020), DOI:10.1088/1757899X/763/1/012006.

19 B. Andrana, D. U. C. Rahayu, D. A. Nurani, Y. K. Krisnandi and E. Budianto, IOP Conference Series: Materials Science and Engineering, 763, 012010, 1(2020), DOI:10.1088/1757-899X/763/1/012010.

20 S. Li, X. Qi and B. Huang, Catalysis Today, 276, 139(2016), DOI:10.1016/j.cattod.2015.12.027.

21 I. Ansary and A. Taher, One-Pot Synthesis of Coumarin Derivatives [Online First], IntechOpen, 1-35 (2019), DOI:10.5772/intechopen.89013.

22 S. M. El-Dafrawy, S. M. Hassan and M. Farag, Journal of Materials Research and Technology, 9(1), 13(2020), DOI:10.1016/j.jmrt.2019.09.063.

23 Z. Zhang, C. Xie, L. Feng and C. Ma, Synthetic Communications, 46(18), 1507(2016), DOI: $10.1080 / 00397911.2016 .1213297$.

24 M. R. Khodabakhshi, F. R. Moghaddam and M. Kiamehr, Tetrahedron Letters, 59(51), 4503(2018), DOI:10.1016/j.tetlet.2018.11.022.

25 R. Dey and P. Banarjee, Advanced Synthesis \& Catalysis, 361(12), 2849(2019), DOI: 10.1002/adsc.201801714.

26 S. Bouasla, J. Amaro-Gahete, D. Esquivel, M. I. Lopez, C. Jimenez-Sanchidrian, M. Teguiche and F. J. Romero-Salguero, Molecules, 22(12), 2072(2017), DOI:10.3390/molecules22122072.

27 P. Selvam, N. Ramlakshmi, G. Uma, S. A. Kumar and A. Umamaheswari, Rasayan Journal of Chemistry, 3(2), 275(2010).

28 O. S. Chavan, S. A. Jadhav, M. G. Shioorkar, S. B. Chavan, M. A. Baseer and D. B. Shinde, Rasayan Journal of Chemistry, 8(2), 194(2015).

29 P. N. Kalaria, S. P. Satasia, V. B. Purohit, J. R. Avalani, N. H. Sapariya and D. K. Raval, Polycyclic Aromatic Compounds, 1-11 (2019), DOI:10.1080/10406638.2019.1666887.

[RJC-5808/2020] 